\title{
Synthesis
}

\section{Resilience, Panarchy, and World-Systems Analysis}

\author{
Nicholas M. Gotts ${ }^{1}$
}

\begin{abstract}
The paper compares two ambitious conceptual structures. The first is the understanding of social-ecological systems developed around the term "resilience," and more recently the term "panarchy," in the work of Holling, Gunderson, and others. The second is Wallerstein's "world-systems" approach to analyzing hierarchical relationships between societies within global capitalism as developed and applied across a broader historical range by Chase-Dunn and others. The two structures have important common features, notably their multiscale explanatory framework, links with ideas concerning complex systems, and interest in cyclical phenomena. They also have important differences. It is argued that there are gaps in both sets of ideas that the other might remedy. Their greatest strengths lie at different spatiotemporal scales and in different disciplinary areas, but each also has weaknesses the other does not address, particularly with regard to the mechanisms underlying proposed cyclic patterns of events. The paper ends with a sketch for a research program within which panarchical and world-systems insights might be synthesised in the study of the "Great European Land-Grab," i.e., the expansion of European capitalism and its distinctive social-ecological systems over the past five centuries.
\end{abstract}

Key Words: adaptive cycle; cross-scale interaction; panarchy; population; resilience; technology; worldsystems.

\section{INTRODUCTION}

"Panarchy" refers here to the framework for conceptualizing the type of coupled humanenvironment systems described in Gunderson and Holling (2002) and more briefly, with some changes, in Walker et al. (2006). This framework may be divided into two parts, referred to here as "the resilience conceptual framework" and "the adaptive cycle metaphor." This paper critically compares aspects of panarchy with the "worldsystems" framework (Wallerstein 1974, 1993, Denemark et al. 2000, Hall 2000), specifically the variant of world-systems analysis developed by Chase-Dunn and colleagues (Chase-Dunn and Hall 1997a,b, Chase-Dunn and Babones 2006). The two approaches have much in common as well as important differences. Their commonalities include seeking broad-scale patterns in human social systems and explaining them in terms of processes that affect multiple, distinct, but interacting spatial and temporal scales. They also have close links with ideas about complex systems (Holland 1992, 1998) and place considerable emphasis on cyclic phenomena, an interest they inherit from Schumpeter $(1939,1943)$ and, via Schumpeter in the panarchist case, Kondratieff (1979 [1926]), alternatively transliterated as "Kondratiev." Major differences include the focal scale, which is regional for panarchy and planetary for world-systems; greater emphasis on ecological processes and social-ecological interactions in panarchy and on economic, political, and military processes in world-systems theory; and more attention within world-systems analysis to directional change over the course of multiple cycles.

\section{THE PANARCHICAL FRAMEWORK}

For my purposes here, the following aspects of the panarchical view of ecological and socialecological systems are central. 


\section{The resilience conceptual framework}

Characteristics of the resilience conceptual framework include:

1. multiple metastable regimes. Rather than a single equilibrium point, such systems generally have multiple metastable regimes. Within each regime, change may occur, but the set of dynamically important variables and interactions remains fixed.

2. the importance of episodic change. Systems with multiple metastable regimes may switch rapidly between them as critical thresholds are passed. Furthermore, hysteresis is common.

3. resilience. Holling and Gunderson (2002:28) define ecosystem resilience as " ... the magnitude of disturbance that can be absorbed before the system changes its structure by changing the variables and processes that control behavior." Resilience in this sense is central to the resilience conceptual framework.

4. multiple distinctive scales with cross-scale interactions. Holling et al. (2002c:72) argue that ecological and social-ecological systems form a multilevel hierarchical structure, but that the different levels are of distinct kinds, i.e., the structure is not scale-free.

\section{The adaptive cycle metaphor}

The characteristics of the adaptive cycle metaphor include:

1. a four-phase adaptive cycle. Holling and Gunderson (2002:32) suggest that most, although not all, such systems follow a fourphase cycle of (1) "exploitation" (r); (2) "conservation" (K); (3) "release" $(\Omega)$ or "creative destruction," a term derived from Schumpeter (1943); and (4) "reorganization" $(\alpha)$. The first two stem from standard ecological theory, in which an ecosystem's $r$ phase is dominated by colonizing species tolerant of environmental variation and the $\mathrm{K}$ phase, by species adapted to modulate such variation. However, Holling and Gunderson (2002) say that " ...two additional functions are needed." The corresponding phases, especially $\Omega$, are typically much briefer: in a forest, $\Omega$ might be a fire or insect outbreak that frees nutrients from biomass, whereas the $\alpha$ phase involves soil processes limiting nutrient loss. The adaptive cycle involves changes in three main variables: resilience; potential in the form of accumulated resources in biomass or in physical, human, and social capital; and connectedness, meaning the tightness of coupling among the controlling variables that determine the system's ability to modulate external variability. In the $r$ phase, potential and connectedness are low but resilience is high; in $\mathrm{K}$, resilience decreases while the other values increase. Eventually, some internal or external event triggers the $\Omega$ phase, in which potential crashes; finally, in $\alpha$, resilience and potential grow, connectedness falls, unpredictability peaks, and new system entrants can establish themselves. Holling and Gunderson (2002) stress that the adaptive cycle is a metaphor that can be used to generate specific hypotheses; exact interpretations of resilience, potential, and connectedness are system dependent.

2. panarchy. Ecological and social-ecological systems form nested sets of adaptive cycles. The larger, slower cycles generally constrain the smaller, faster ones and maintain system integrity, but, during the $\Omega$ and $\alpha$ phases, critical cross-scale interactions can operate, particularly "Revolt" connections, in which an $\Omega$ phase collapse on one level triggers a crisis one level up, and "Remember" connections, in which the $\alpha$ phase of a cycle is organized by a higher-level $\mathrm{K}$ phase. The Revolt and Remember forms of cross-scale interaction, and panarchy itself as described in Holling et al. (2002c), assume that the hierarchically related systems are following adaptive cycles.

3. three distinct kinds of change. Holling et al. (2002a) identify three types of change within panarchies: incremental change in the $r$ and $\mathrm{K}$ phases, which are smooth and fairly predictable; abrupt change in the transitions from $\mathrm{K}$ through $\Omega$ and $\alpha$; and transformational learning, meaning change 
involving several panarchical levels, and interaction between different sets of labile variables.

The resilience conceptual framework underlies a broad body of work, including a considerable number of detailed studies of regional socialecological systems (see any issue of Ecology and Society, and most of the chapters in Gunderson and Holling 2002 and Berkes et al. 2003). This body of work has now reached a state in which systematic comparisons can be made, particularly with regard to thresholds and regime shifts (Walker and Meyers 2004, Groffman et al. 2006). A significant subset of recent work within the resilience conceptual framework explores or makes use of the adaptive cycle metaphor to varying degrees, and this paper focuses primarily on these, but also draws on the broader resilience literature.

\section{WORLD-SYSTEMS ANALYSIS}

World-systems analysis (Wallerstein 1974, Denemark et al. 2000, Chase-Dunn and Hall 1997a, Hall 2000) centers on the premise that the modern world cannot be understood without considering it as a whole, and over long periods of time. The stances of worldsystems researchers differ considerably, but all would agree with the first point below, and most with points $2-7$.

1. "... the most important unit of analysis for the study of social change is not societies or states but the entire world-system. Changes in organization are not endogenous to individual societies. Rather, they are a consequence of complex interactions among local, regional, societal, and global processes." (Chase-Dunn and Hall 1997a:1). A world-system is not necessarily planetary in scope, but does necessarily include multiple societies or polities, with long-term, highly structured interrelationships.

2. Within the current world-system, there is a geographical division of labor, with strong hierarchical features, between "core," "semiperipheral," and "peripheral" regions. The most sophisticated economic activities are concentrated in core states, which are also the strongest and best integrated. Peripheral regions are economically subordinate, generally supplying raw materials or low- quality goods. The semi-periphery hosts a mixture of corelike and peripheral activities.

3. Individual states may move within the hierarchy, but upward mobility is constrained by their trade relations within the world economy and their geopolitical role and power.

4. Political, economic, and military interactions between states are central to the maintenance of elites within those states. Core elites accumulate many of their resources from the periphery and semi-periphery, use some of those resources to buy support and/or pay armed forces, and often maintain subordinate elites in noncore areas.

5. States and corporations are both essential to the operation of the modern world-system. Core corporations are the major economic actors, but rely on states to protect their assets and market access. The existence of multiple states stabilizes the system by allowing corporations mobility, thus limiting how far any state can tax or regulate them.

6. There are important cyclical processes in world-system economics and interstate politics. The most widely discussed is the approximately 50-yr Kondratieff cycle of economic activity (Schumpeter 1939, Kondratieff 1979 [1926]). This is widely but by no means universally acknowledged to exist by economic historians. It shows up best in price series (Berry et al. 2001), and there is broad agreement that each cycle involves a wave of technological innovation. Within world-system analysis, Kondratieff and other cycles are generally seen as aspects of longerterm directional processes; in particular, the innovations of each Kondratieff cycle are generally retained. More specific to worldsystem analysis is the longer "hegemonic cycle" affecting the distribution of economic, political, and military power among core states.

7. The modern world-system came into being with the growth of European capitalism and overseas expansion of European states around 1500, and now includes the whole world. 
World-system theorists differ on how worldsystems work, and how earlier intersocietal systems differ from the modern world-system. This paper concentrates on the version of world-system analysis developed in Chase-Dunn and Hall (1997a) and Chase-Dunn and Babones (2006), which proposes an iteration model of world-system evolution intended to apply to all the intersocietal systems between the origins of sedentism and the present. The main points of this model are as follows:

1. Population growth and consequent intensification of productive activity lead to environmental degradation and hence to population pressure, defined as the increased labor required as a result of environmental degradation.

2. The first response to this pressure is generally emigration, but if there are no accessible and suitable uninhabited regions, this leads to intersocietal conflict.

3. This conflict may be sufficient to reduce the population pressure, but may also lead to the formation of larger polities and extended social hierarchies, reducing conflict but also stimulating technological changes, which are needed to maintain and exploit the new social arrangements.

4. Technological change itself may feed back into further hierarchy formation and reduce the immediate population pressure by allowing greater production efficiency, but in the longer term it encourages further population growth.

5. Institutional innovations can sometimes accelerate technical innovation, hierarchy formation, and polity growth beyond what the cycle of stages 1-4 above would produce.

The major institutional innovations in this model are transformations between predominant "modes of accumulation" that modify the workings of the iteration cycle. The two most important occurred when chiefdoms developed into states, which happened on several independent occasions, and when capitalism developed in Western Europe. Chiefdom-state transitions replaced primarily normative systems of obligation based on real or mythical kinship, with tributary systems in which labor, taxes, and tributes are exacted by systematic armed coercion from slaves, peasants, and weaker neighboring societies, as the main way for elites to accumulate resources. The development of capitalism replaced this in turn with the predominance of profit derived from commodity production and exchange, which provide incentives for innovation independent of direct population pressure, as noted in point 5 above. Price-setting markets, wages, credit, and other capitalist institutions all long preceded the capitalist worldsystem, but, until the 17 th century, the only states with primarily capitalist elites had been city states overshadowed by their far more powerful tributebased neighbors.

Chase-Dunn's model attributes particular importance to the semi-periphery as the site of many major innovations, because these societies have more resources than peripheral societies but are less invested in the old ways than core societies are. Hall and Chase-Dunn (2006) present a number of historical examples, including semi-peripheral societies that founded large empires incorporating what had been former core societies, e.g., the Persian, Macedonian, Roman, Ottoman, and Manchu empires; capitalist city-states such as Tyre, Carthage, Malacca, Venice, and Genoa, which pioneered new trades and industries; and the rise of successive hegemons or leading powers of the capitalist system such as the Dutch Republic, the UK, and the United States. The rise of western Europe itself is held to have occurred from a semiperipheral position in a multicore world-system, linked by trade in prestige goods and information exchange, that encompassed much of Afroeurasia, i.e., Eurasia plus Africa, during the medieval period.

According to Hall and Chase-Dunn (2006), the problems of environmental degradation and population pressure and conflict have not so far been solved, but rather shifted upscale. Early worldsystems analysis paid little heed to specific or regional environmental issues, but in the last decade two special issues of the Journal of World-Systems Research have been dedicated to environmental issues. A number of the articles are comparative, linking world-system position, i.e., core, semiperipheral, or peripheral, with indices of environmental damage or impact. Core states, as the homelands of the strongest elites, might be expected to avoid or remedy forms of environmental damage that would threaten the welfare of the elite, and perhaps that of the general population, whose 
support or acquiescence is extremely helpful. However, they may well choose not to control pollution that has only dispersed, long-term effects. Peripheral and semi-peripheral states would be expected to suffer from the effects of environmentally damaging extractive industrial activities that are often controlled by core-state corporations.

Generally, these expectations are borne out. Bartley and Bergesen (1997) cite several quantitative studies indicating that deforestation is most intense in the semi-periphery, where the demand for timber for construction is high but little reforestation occurs. In contrast, Burns et al. (2003) find the highest rates of deforestation in the periphery, which they attribute to recently intensified deforestation there; their own earlier work is cited in Bartley and Bergensen (1997). With regard to greenhouse gas emissions, Burns et al. (1997) report that $\mathrm{CO}_{2}$ output declines monotonically from core to periphery, whereas states in a "semi-core" category, which they define as being between core and semiperiphery, produce most of the world' $\mathrm{CH}_{4}$ because of their heavy reliance on livestock farming. Grimes and Kentor (2003) find that the penetration of foreign capital raises $\mathrm{CO}_{2}$ production, which they attribute to the fact that transnational corporations tend to relocate environmentally unfriendly production to countries with fewer environmental controls. Roberts et al. (2003) add that, when the amount of $\mathrm{CO}_{2}$ released per unit of economic output is considered, semi-peripheral and "upper peripheral" countries, which depend heavily on foreign capital, do the worst. In a more regionally focused study, Frey (2003) analyzed examples of transfers of industrial processes from the United States, which is part of the core, to the northern border region of Mexico, which is in the semiperiphery. The increased environmental regulation in the United States is one reason for this, and the rapid growth of population and hazardous industrial processes has caused multiple forms of environmental damage.

Among the special issue articles, Bunker (2003) examines the social-ecological history of a specific region in the most detail, analyzing $400 \mathrm{yr}$ of raw material extraction from the Amazon and demonstrating the interactions of regional topography, climate, and ecology with advances in transport technology and the increasing and changing demands of core economies. Each extractive episode involved the transport of greater volumes of goods, from spices to turtle oil to fine woods to rubber to iron ore, more cheaply over greater distances. Some of these products became obsolete, leading to regional economic downturns, e.g., turtle oil when mineral oils came into greater use, and rubber when the rubber tree was domesticated and grown in plantations in southeast Asia. In the Amazon, rubber trees cannot grow close to each other because of an endemic fungus, an important driver of domestication efforts, and hence the replacement of distant native forests by rubber plantations. An iron ore extraction project in the 1980s, driven by rising world demand, brought many workers to construct transport infrastructure. Laid off when construction ended, they began farming, in turn damaging Brazil nut production. The Brazil nut tree needs to be surrounded by other trees for shelter and to support a pollinating bee. Thus, Bunker elucidates the cross-scale linkages that, over the past four centuries, have tied the Amazon basin into the world-system and its technological development, changed its ecology, and also allowed its ecology to influence distant regions.

\section{CRITICISMS AND POSSIBLE SYNERGIES}

In this section, some criticisms of each of the approaches discussed are identified, and it is considered how far each might compensate for weaknesses in the other.

Taking the resilience conceptual framework first, points 1-4 above are not questioned here; criticisms of this framework are purely in terms of what it neglects. The adaptive cycle metaphor has been criticized from within the resilience conceptual framework; these criticisms are extended here.

There is general agreement that the four-phase adaptive cycle is not universal across ecological and social-ecological systems: Holling and Gunderson (2002:53-60) themselves describe systems stuck in one region of the three-dimensional space defined by connectivity, potential, and resilience. However, more fundamental criticisms of the adaptive cycle metaphor, and specifically of whether this threedimensional space adequately represents the key aspects of ecosystem functioning, have recently emerged within the resilience literature. Janssen et al. (2006) distinguish three network characteristics relevant to resilience: centrality, i.e., the existence of key nodes, and two aspects of connectivity, 
density of links and reachability of nodes from each other, which are only partially independent. They found no simple connectivity-resilience relation. Abel et al. (2006) found the theory of the adaptive cycle useful for recognizing changes in system behavior during the various phases. However, they found several anomalies as well. The phases did not necessarily occur in the order proposed, there was no support for a fall in resilience during the $K$ phase or for a clustering of events late in $\mathrm{K}$, and the potential/connectedness distinction was not useful, so they replaced it with the concepts of natural, physical, human, social, and financial "capitals."

Turning to cross-scale interactions, they found evidence of cross-scale effects outside the Revolt and Remember templates. In particular, government intervention and, more generally, the ability of power groups to appropriate resources were crucial both in maintaining regional rangeland systems in a particular condition in Zimbabwe and New South Wales and in causing regional collapses. They also noted that the social-ecological systems of Australian Aboriginals collapsed because of British colonization, with no reason to believe that these systems were intrinsically unstable. When describing a social-ecological system in Western Australia, Allison and Hobbs (2004) identified the drivers of its cyclical behavior as the 45-60 yr Kondratieff cycles of global economics, which produced alternating periods of favorable and unfavorable market conditions of roughly equal length, rather than internal dynamics of long, slow accumulation of capital separated by short periods of rapid change.

Thus it is not clear that system collapses are usually due, even in part, to internal dynamics. If a system on a more-or-less predictable trajectory spends a short time in its early phases and a longer time in later ones, as in the classic $\mathrm{r}$ to $\mathrm{K}$ succession from annuals to perennials to shrubs to trees, then an externally triggered collapse is most likely to occur in the later phases, even if the probability of collapse per unit time remains constant or falls. Conversely, economic and politically mediated links with larger national or transnational systems may be primary determinants of events, rather than merely constraining or triggering factors in the dynamics of the regional system. In such cases, world-systems analysis may have much to offer. It should be noted that the planetary social-ecological system is at the top of a hierarchy; although it is part of larger systems such as the Earth, solar system, and galaxy, these systems are not themselves social-ecological systems. The dynamics of the topmost member of a hierarchy of systems of a particular type must surely have some special features; nothing in the panarchist framework contradicts this, but neither does it appear to have received much attention.

There is a systematic ambiguity in the term "adaptive," as used in "adaptive cycle." The key question is: What adapts? In Holland (1992:184-185), adaptation is a property of organisms or of analogous components of an artificial system. In this context, entities that adapt show a characteristic subordination of their parts to the interests of the whole, just as the interests of the individual cells of a healthy animal are subordinated to those of the organism. In explanations of the adaptive cycle metaphor, it frequently appears that the system as a whole adapts and shows an analogous subservience of parts. This is explicit in Holling and Gunderson (2002): in the justification for adding the functions $\Omega$ and $\alpha$ quoted above, in " ... the cycle shifts into a 'backloop' to reorganize accumulated resources for the initiation of a new cycle" (Holling and Gunderson 2002:41), and in their intuition (Holling and Gunderson 2002:47) that any complex system, if adaptive, must alternate between the "objectives" of maximizing first production and accumulation, then invention and reassortment. However, in the words of the resilience researcher Levin (2001): “ ... the ecosystem is not an organism and has not been shaped by evolution to perform particular functions, at least, so far as has been shown." After arguing that natural selection acting on individuals can produce a form of hierarchical organization within an ecosystem in which most species interact strongly with only a few others, and that this can favor ecosystem resilience, Levin (1999) notes that features that reduce resilience, such as the existence of keystone species, can evolve in the same way. From this viewpoint, ecosystems can become either less or more resilient as they become more connected, depending on the details of the connection networks concerned.

Although the panarchical perspective admits political conflict, it has had little to say about social elites and the often violent and oppressive ways in which they maintain themselves. Nevertheless, elites and violent conflict are fundamental to social dynamics and highly relevant to environmental sustainability. Homer-Dixon and Blitt (1998) show how environmental scarcity interacts with power differences to generate destitution, violence, and 
further environmental destruction; conversely, Diamond (2005) argues that the highly stable Tokugawa shogunate in Japan was able to enforce society-wide measures to reverse deforestation. From the panarchical perspective, Abel et al. (2006) work on political influences on rangeland systems has already been mentioned. Pritchard and Sanderson (2002) note that, even in pluralist political systems, some interest groups can circumscribe debate and shape public preferences, hiding objectively divergent interests, and Alcorn et al. (2003) analyze how the Indonesian state has legitimized elite interests and, in doing so, undermined Dayak social-ecological system management. However, today's most powerful agents, states and large corporations, with their economic power, media influence, and, for states, armed forces, remain largely unanalyzed. These agents largely determine what kinds of disturbances regional systems need resilience against. Here, perhaps more than anywhere else, world-systems analysis could strengthen work within the resilience conceptual framework.

The panarchical perspective has also had little to say about the long-term growth of world population, energy use and polity size, and the power of technology available for human use. As with the comparative neglect of conflict and elite dynamics, this is perhaps unsurprising, given its disciplinary roots in economics, ecosystem science, institutional research, and adaptive complex system theory (Holling 2003). However, all these factors have enormous implications for the past and future development of social-ecological systems at all scales.

The cumulative nature of technological development and its ability to construct successive layers of designed novelty differentiate it from the nested adaptive cycles of panarchy, although there are cyclic aspects to the replacement of one technical or socio-technical regime by another (Smith 2003, van der Brugge et al. 2005), and techniques can be lost or abandoned. Technological development has seemingly tended to accelerate. Chronologies of major technological innovations usually become denser toward the present (Modis 2002), but this could be because of the differential availability of information, or the perception of which innovations are important. However, there is another line of evidence: long-term human population growth. Until the 1970s, the proportional rate of growth rose almost monotonically for $2000 \mathrm{yr}$ (Johansen and
Sornette 2001), and probably far longer (Kremer 1993). This is explicable if population density has been limited by available technology, and larger populations innovate faster as evidence from Kremer (1993) indicates, perhaps simply because in total they give more time to it.

The analysis above does not mean population growth and innovation can accelerate indefinitely. Cohen (1995) explores the consequences of assuming that population growth rate will rise with the spare carrying capacity for additional population, while population growth will, via innovation, increase carrying capacity. This can imply either a singularity, with infinite population reached in a finite time, endless exponential growth, or super-exponential growth giving way to logistic growth so that the population levels off, depending on how innovation's ability to increase carrying capacity itself changes with increasing population.

Such models depend on innovations being able to spread across a population. Koratayev (2005) notes that, by the first millennium BCE, iron metallurgy was able to spread from its southwest Asian origin to the Atlantic and Pacific coasts of Afroeurasia within a few centuries. Because iron axes and plows are far more efficient than earlier forest-clearing and tillage tools, this must have transformed agroecosystems across much of the Earth. Pacey (1990) details extensive technological exchanges between Afroeurasian civilizations in the period 700-1450 $\mathrm{CE}$. Thus the Afroeurasian regions, which include most of the Earth's population, have in terms of technical innovation formed a single, although decentralized, system for millennia. The history of innovation challenges the linkage of "small" with "fast" and "large" with "slow" in descriptions of panarchies; human social and technical systems have often become larger and faster-changing simultaneously. Clear examples come from historical changes in communication and transport networks. In recent centuries, largely Europeanderived changes in transport, communication, and military technologies have drastically reduced the autonomy of regional-scale systems.

Of the work cited above, only Koratayev (2005) derives directly from a world-systems perspective. Moreover, the apparent direct influence of population size on innovation speed requires an addition to the iteration model of world-system evolution. World-systems analysis has stressed institutional more than technological change, and in 
this regard may require some rebalancing, but it has been much more alive than panarchist researchers to the work on technological change described above.

Whereas studies cited earlier show that significant work on regional social-ecological systems from a world-systems perspective is under way, there is nothing to match the breadth and depth of regional studies or of comparative work on thresholds and regime change within the resilience conceptual framework. Moreover, although the two frameworks share a concern with the factors that make for stability or instability in systems, and specifically the insight that measures taken to preserve a desired system feature can lead to eventual collapse and radical reconfiguration of the system, the developing theoretical and empirical work on the assessment of system resilience (Carpenter et al. 2005, Cumming et al. 2005) has no world-systems parallel.

World-systems analysis also has problems that have no relation whatsoever to panarchy. One is the difficulty of operationalizing the semi-periphery concept; Chase-Dunn and Hall (1997a), provide five overlapping meanings for the term. Another relates to the significance, timing, and underlying mechanisms of Kondratieff, hegemonic, and other cycles. The mechanism of Kondratieff cycles has not been agreed upon even by those who accept their existence, and, although most world-systems theorists accept the Dutch Republic, UK, and United States as successive hegemons, some (e.g., Modelski 2000) trace the series even further back. Furthermore, it is clear that the successive instances of hegemony were very different. In particular, the Dutch Republic's peak share of global economic activity was much less than the UK's, and the latter was much less than that of the United States. Again, although all world-system networks are said to pulsate and all but kin-based world-systems are considered to have cycles of centralization and decentralization (Chase-Dunn and Hall 1997a:251), detailed mechanisms and the degree of regularity to be expected have not been established. A third such weakness concerns the relationship of population to innovation. Aside from the point made above, the demographic transition, which has led to declining populations in some core states, does not appear to fit the iteration model, even when it is modified to take into account innovation without population pressure under capitalism.
In summary, the panarchical framework and worldsystems analysis each have weaknesses the other does not address, and they perhaps share an excessive expectation that homologous cyclic patterns of change will recur across a wide range of situations, given the absence of sufficiently wellspecified mechanisms underlying these cyclic patterns. However, the two have strengths in complementary areas, suggesting considerable potential for synergy. Existing work in both traditions (e.g., Bunker 2003, Allison and Hobbs 2004) shows what can be done when analyses of planetary and regional scales and of ecology, politics, and technology are integrated.

\section{UNDERSTANDING RADICAL GLOBAL CHANGE}

Holling (2004) assesses the possibility of using the ideas that are central to panarchy, developed on a regional scale, to help explain the changes that are being brought about on a global scale by the Internet and by climate, economic, and geopolitical changes. He suggests that the "international world of nations" entered the backloop $\Omega$ and $\alpha$ phases of an adaptive cycle with the 1989 fall of the Berlin Wall. However, the subsequent years have seen continued economic growth, technical intensification, growth of transnational corporations, and primacy of the United States; all these date at latest from 1945 and appeared most threatened during the 1970s with the American defeat in Indo-China, the oil shocks, and "stagflation." Holling identifies the Internet as a backloop phenomenon and regards the "global interconnected communications-driven revolution" as a third major transformation after the agricultural and industrial revolutions. However, this has been a very long revolution, under way, in successive waves, for more than two centuries when we consider the telegraph (first visual, then electric), telephone, radio, and television.

It seems impossible to assign the planetary socialecological system convincingly to any phase of the adaptive cycle. Connectedness and certain kinds of potential are rising, and resilience is probably falling, suggesting that we are in a K phase. At the same time, continuing rapid innovation suggests an $r$ phase, whereas the growing release of stored energy from fossil fuels, plus soil erosion, extinctions, and deforestation would seem to indicate $\Omega$. In contrast, although they disagree on much else, Berry (2000), Devezas et al. (2005), and 
the world-systems analyst Goldstein (2006) agree that the Kondratieff cycle should produce rising growth and inflation, and technological diffusion rather than radical innovation, over the next decade or more.

Whether through war, full-scale ecological collapse, or a technological and/or socio-political revolution, it seems certain, as Holling (2004) notes, that radical global change is coming in this century, but this is evident even without the panarchical perspective. We urgently need the scientific tools to understand the range of possibilities open to us. Combining the panarchical perspective's strengths at the regional scale and its key concept of resilience with the insights of world-systems theory could yield an understanding neither can provide alone. This paper ends by sketching a research program within which this could be attempted.

\section{A suggested research program}

Crosby (2004) shows how European imperialism, dependent on technical developments, both led to and was facilitated by the introduction, both deliberate and accidental, of European organisms to the "neo-Europes" of Australasia and temperate America, transforming them ecologically as well as socially and technically. This "Great European Land-Grab" is neither a Revolt nor a Remember connection, but rather a takeover of many autonomous systems by a more innovative system at the same hierarchical level. Holling et al. $(2002 c: 96)$ refer to Crosby's work, but only with regard to societies that collapse under the effects of both ecological and economic imperialism. The dynamics producing this imperial expansion and those of the resulting expanded system remain unexamined, although it is this system, the focus of world-systems approaches, that we all inhabit.

As Holling et al. (2002b) argue, one road to understanding current global change is by analogy with past events. They propose finding such analogies in regional systems that have collapsed and recovered in the recent past, and these could indeed be fruitful. However, the Great European Land-Grab was a planetary-scale process; if it leads to collapse, there is no containing system from which to draw resources for recovery. It revolutionized global distributions of societies, technologies, and agro-ecosystems and has imposed strong, directional change on effectively all recent regional systems.
The scientific study of unique events is always difficult, but two potential strategies are to find events that share as many of their most important features as possible and to compare spatiotemporally defined parts of such events with each other. To follow the first strategy, I suggest seeking other situations in which populations from a large, rapidly innovating social-ecological system exploited new opportunities to cross longestablished boundaries and invade more stable regions, subjecting those regions, and sometimes themselves, to profound transformation. ChaseDunn and Hall (1997a) have already compared the western European rise to core status and the subsequent expansion of the world-system with other world-system expansions and mergers, and other cases of semi-peripheral rise, but say rather little about the ecological aspects of these events.

Within human history and prehistory, the following sources of case studies are suggested:

- $\quad$ The first appearance of humans, plus their commensals and parasites, in previously unsettled areas, e.g., Iceland, other Atlantic islands, Madagascar, Polynesia, AustraliaNew Guinea, and the Americas. Diamond (2005) includes some comparative studies. Comparing the ecological results of takeovers of such pristine ecosystems with those already modified by human inhabitants should be enlightening.

- $\quad$ The expansion of Iron Age Bantu-speaking agriculturalists across central and southern Africa, largely displacing or absorbing existing gathering populations and transforming the ecosystem (Vogel 1997). This was the last major geographical expansion of the Afroeurasian system before European colonialism and was probably fuelled by the spread of iron metallurgy to West Africa. Novel linguistic and genetic methods are currently transforming the prospects for reconstruction of population movements such as this, for which written records do not exist (Cavalli-Sforza 2000), and are now being applied to this episode (Beleza et al. 2005, Rexová et al. 2006).

- Greek colonzation around the Mediterranean and Black Sea in the 8th to 6th centuries BCE. Like the Great European Land-Grab, this was an overseas expansion stemming from multiple rival polities in a littoral region (McEvedy 2002); it was also linked to both 
political and technical innovation, although with less radical effects on colonized areas. Littoral regions may favor innovation through high diversity and trade and information networks with many links per node. It should be noted that this expansion from semi-peripheral into peripheral areas, like the European colonization of the previously out-of-system neo-Europes, was followed by predominance in the former core: Alexander's conquest of the Achaemenid Empire.

- The expansion of anatomically modern humans from Africa, displacing earlier Homo populations in Eurasia. Although the triumph of the newcomers is conventionally attributed to their cognitive superiority, Oppenheimer (2003) argues that, at least in comparison with the Neandertals, the important differences were probably cultural, which would strengthen the parallel.

The second strategy mentioned above is to compare parts of the Great European Land-Grab with each other. First, it would be worth comparing those few areas that never came under formal European rule or protection, which are all in eastern or southern Asia, apart from the single case of Antarctica, with the much greater areas that did. Do they show either less cumulative social-ecological change, or a different pattern of change? Did they have common features that prevented European colonization, or was their exemption from it a matter of chance? Second, we might compare those colonizations that involved displacing or subordinating existing populations with those few, principally on Atlantic Islands, which did not. Particularly interesting comparisons might be drawn between the Canaries, which had a pre-European population, and the Azores, Madeiras, and Cape Verde, which did not. Among the colonized areas with pre-existing populations, systematic comparisons could be made between:

- those within, on the edge of, and beyond the medieval Afroeurasian world-system;

- those within Crosby's neo-Europes and others;

- those in which the colonized had different technological, cultural, and immunological resources;
- those colonized by different groups of Europeans or at different times; and

- those in which Europeans forced or encouraged other groups to migrate to the colonized lands and those in which they did not.

These distinctions are not independent but do cut across each other, and it might pay to give particular attention to unusual cases such as Siberia, the only area within Afroeurasia in which colonizing Europeans became the majority population, and to marginal cases such as South Africa, where conditions were favorable enough ecologically for mass European settlement to occur but the existing population remained a majority.

Studying the similarities and differences between these and other episodes of radical change involving the transgression of long-established boundaries between social-ecological systems is perhaps our best hope of understanding current global turbulence and hence improving our survival prospects.

Responses to this article can be read online at:

http://www.ecologyandsociety.org/vol12/iss 1/art24/responses/

\section{Acknowledgments:}

Work for this paper was funded by the Scottish Executive Environment and Rural Affairs Department under the "Environment - Land Use and Rural Stewardship" Programme, and by the European Commission under the Sixth Framework Programme CAVES project, no. 012816. Thanks to Robin Matthews and two anonymous referees for useful comments on earlier versions.

\section{LITERATURE CITED}

Abel, N., D. H. M. Cumming, and J. M. Anderies. 2006. Collapse and reorganization in socialecological systems: questions, some ideas, and policy implications. Ecology and Society 11(1):17. [online] URL: http://www.ecologyandsociety.org/vol11/ iss1/art17/. 
Alcorn, J. B., J. Bamba, S. Masiun, I. Natalia, and A. G. Royo. 2003. Keeping ecological resilience afloat in cross-scale turbulence: an indigenous social movement navigates change in Indonesia. Pages 299-327 in Berkes, F., J. Colding and C. Folke, editors, Navigating social-ecological systems: building resilience for complexity and change. Cambridge University Press, Cambridge, UK.

Allison, H. E., and R. J. Hobbs. 2004. Resilience, adaptive capacity, and the "lock-in trap" of the western Australian agricultural region. Ecology and Society 9(1):3. [online] URL: http://www.ecologya ndsociety.org/vol9/iss1/art3/.

Bartley, T., and A. Bergesen. 1997. World-system studies of the environment. Journal of WorldSystems Research 3(3):369-380. Available online at: http://jwsr.ucr.edu/archive/vol3/v3n3a1.php.

Beleza, S., L. Gusmão, A. Amorim, A. Carracedo, and A. Salas. 2005. The genetic legacy of western Bantu migrations. Human Genetics 117(4):366-375.

Berkes, F., J. Colding, and C. Folke, editors. 2003. Navigating social-ecological systems: building resilience for complexity and change. Cambridge University Press, Cambridge, UK.

Berry, B. J. L. 2000. A pacemaker for the long wave. Technological Forecasting and Social Change 63(1):1-23.

Berry, B. J. L., H. Kim, and E. S. Baker. 2001. Low-frequency waves of inflation and economic growth: digital spectral analysis. Technological Forecasting and Social Change 68(1):63-73.

Bunker, S. G. 2003. Matter, space, energy, and political economy: the Amazon in the worldsystem. Journal of World-Systems Research 9 (2):219-258. Available online at: http://jwsr.ucr.edu// archive/vo19/number2/pdf/jwsr-v9n2-bunker.pdf.

Burns, T. J., B. L. Davis, and E. L. Kick. 1997. Position in the world-system and national emissions of greenhouse gases. Journal of World-Systems Research 3(3):432-466. Available online at: http://j wsr.ucr.edu/archive/vol3/v3n3a4.php.

Burns, T. J., E. L. Kick, and B. L. Davis. 2003. Theorizing and rethinking linkages between the natural environment and the modern world-system: deforestation in the late 20th century. Journal of World-Systems Research 9(2):356-390. Available online at: http://jwsr.ucr.edu//archive/vol9/number2/ pdf/jwsr-v9n2-bkd.pdf.

Carpenter, S. R., F. Westley, and M. G. Turner. 2005. Surrogates for resilience of social-ecological systems. Ecosystems 8(8):941-944.

Cavalli-Sforza, L. L. 2000. Genes, peoples and languages. North Point Press, New York, New York, USA.

Chase-Dunn, C., and S. J. Babones, editors. 2006. Global social change: historical and comparative perspectives. Johns Hopkins University Press, Baltimore, Maryland, USA.

Chase-Dunn, C., and T. D. Hall. 1997a. Rise and demise: comparing world-systems. Westview Press, Boulder, Colorado, USA.

Chase-Dunn, C., and T. D. Hall. 1997b. Ecological degradation and the evolution of world-systems. Journal of World-Systems Research 3(3):403-431. Available online at: http://jwsr.ucr.edu/archive/vol3/ v3n3a3.php.

Cohen, J. E. 1995. Population growth and earth's carrying capacity. Science 269(5222):341-346.

Crosby, A. W. 2004. Ecological imperialism: the biological expansion of Europe 900-1900. Second edition. Cambridge University Press, Cambridge, UK.

Cumming, G.S., G. Barnes, S. Perz, M. Schmink, K. E. Sieving, J. Southworth, M. Binford, R. D. Holt, C. Stickler, and T. Van Holt. 2005. An exploratory framework for the empirical measurement of resilience. Ecosystems 8(3):975-987.

Denemark, R. A., J. Friedman, B. K. Gills, and G. Modelski, editors. 2000. World system history: the social science of long-term change. Routledge, London, UK.

Devezas, T. C., H. A. Linstone, and H. J. S. Santos. 2005. The growth dynamics of the Internet and the long wave theory. Technological Forecasting and Social Change 72(8):913-935.

Diamond, J. 2005. Collapse: how societies choose to fail or survive. Penguin Books, London, UK. 
Frey, R. S. 2003. The transfer of core-based hazardous production processes to the export processing zones of the periphery: the Maquiladora centers of northern Mexico. Journal of WorldSystems Research 9(2):317-354. Available online at: http://jwsr.ucr.edu//archive/vol9/number2/pdf/jwsrv9n2-frey.pdf.

Goldstein, J. S. 2006. The predictive power of long wave theory, 1989-2004. Pages 137-144 in T. C. Devezas, editor. Kondratieff waves, warfare, and world security; proceedings of [a] NATO Advanced Research Workshop (Covilhã, Portugal, 2005). IOS Press, Amsterdam, The Netherlands.

Grimes, P., and J. Kentor. 2003. Exporting the greenhouse: foreign capital penetration and $\mathrm{CO}_{2}$ emissions 1980-1996. Journal of World-Systems Research 9(2):261-275. Available online at: http://j wsr.ucr.edu/archive/vol9/number2/pdf/jwsr-v9n2grimeskentor.pdf.

Groffman, P. M., J. S. Baron, T. Blett, A. J. Gold, I. Goodman, L. H. Gunderson, B. M. Levinson, M. A. Palmer, H. W. Paerl, G. D. Peterson, N. L. Poff, D. W. Rejeski, J. F. Reynolds, M. G.Turner, K. C. Weathers, and J. Wiens. 2006. Ecological thresholds: the key to successful environmental management or an important concept with no practical application? Ecosystems 9(1):1-13.

Gunderson, L. H., and C. S. Holling, editors. 2002. Panarchy: understanding transformations in human and natural systems. Island Press, Washington, D.C., USA.

Hall, T. D., editor. 2000. A world-systems reader: new perspectives on gender, urbanism, cultures, indigenous peoples and ecology. Rowman and Littlefield, London, UK.

Hall, T. D., and C. Chase-Dunn. 2006. Global social change in the long run. Pages 33-58 in C. Chase-Dunn and S. J. Babones, editors. Global social change: historical and comparative perspectives. Johns Hopkins University Press, Baltimore, Maryland, USA.

Holland, J. H. 1992. Adaptation in natural and artificial systems. Second edition. MIT Press, Cambridge, Massachusetts, USA.

Holland, J. H. 1998. Emergence: from chaos to order. Addison-Wesley, Reading, Massachusetts, USA.
Holling, C. S. 1973. Resilience and stability of ecological systems. Annual Review of Ecology and Systematics 4:1-24.

Holling, C. S. 2003. The backloop to sustainability. Pages XV-Xxi in F. Berkes, J. Colding and C. Folke, editors. Navigating social-ecological systems: building resilience for complexity and change. Cambridge University Press, Cambridge, UK.

Holling, C. S. 2004. From complex regions to complex worlds. Ecology and Society 9(1):11. [online] URL: http://www.ecologyandsociety.org/vol9/ iss1/art11.

Holling, C. S., S. R. Carpenter, W. A. Brock, and L. H. Gunderson. 2002a. Discoveries for sustainable futures. Pages 395-417 in L. H. Gunderson and C. S. Holling, editors. Panarchy: understanding transformations in human and natural systems. Island Press, Washington, D.C., USA.

Holling, C. S., and L. H. Gunderson. 2002. Resilience and adaptive cycles. Pages 25-62 in L. H. Gunderson and C. S. Holling, editors. Panarchy: understanding transformations in human and natural systems. Island Press, Washington, D.C., USA.

Holling, C. S., L. H. Gunderson, and D. Ludwig. $2002 b$. In quest of a theory of adaptive change. Pages 3-22 in L. H. Gunderson and C. S. Holling, editors. Panarchy: understanding transformations in human and natural systems. Island Press, Washington, D. C., USA.

Holling, C. S., L. H. Gunderson, and G. D. Peterson. 2002c. Sustainability and panarchies. Pages 63-102 in L. H. Gunderson and C. S. Holling, editors. Panarchy: understanding transformations in human and natural systems. Island Press, Washington, D.C., USA.

Homer-Dixon, T., and J. Blitt, editors. 1998. Ecoviolence: links among environment, population, and security. Rowman and Littlefield, Lanham, Maryland, USA.

Janssen, M. A., Ö. Bodin, J. M. Anderies, T. Elmqvist, H. Ernstson, R. R. J. McAllister, P. Olsson, and P. Ryan. 2006. Toward a network perspective of the study of resilience in socialecological systems. Ecology and Society 11(1):15. 
[online] URL: http://www.ecologyandsociety.org/voll1/ iss1/art15/.

Johansen, A., and D. Sornette. 2001. Finite-time singularity in the dynamics of the world population, economic and financial indices. Physica A 294 (3/4):465-502.

Kondratieff, N. D. 1979 [1926]. The long waves in economic life. Review 2(4):519-562.

Koratayev, A. 2005. A compact macromodel of world system evolution. Journal of World-Systems Research 11(1):79-93. Available online at: http://jw sr.ucr.edu//archive/vol11/number1/pdf/jwsr-v11n1korotayev.pdf.

Kremer, M. 1993. Population growth and technological change: one million B.C. to 1990. Quarterly Journal of Economics 108(3):681-716.

Levin, S. A. 1999. Immune systems and ecosystems. Ecology and Society 5(1):17. [online] URL: http://www.ecologyandsociety.org/vol5/iss1/ $\underline{\operatorname{art} 17 / .}$.

Levin, S. A. 2001. Fragile dominion: complexity and the commons. Perseus, Cambridge, Massachusetts, USA.

McEvedy, C. 2002. The new Penguin atlas of ancient history. Penguin Books, London, UK.

Modelski, G. 2000. World system evolution. Pages 24-53 in R. A. Denemark, J. Friedman, B. K. Gills, and G. Modelski, editors. World system history: the social science of long-term change. Routledge, London, UK.

Modis, T. 2002. Forecasting the growth of complexity and change. Technological Forecasting and Social Change 69(4):377-404.

Oppenheimer, S. 2003. The real Eve: modern man's journey out of Africa. Carroll and Graf, New York, New York, USA.

Pacey, A. 1990. Technology in world civilization: a thousand-year history. Basil Blackwell, Oxford, UK.

Pritchard, L. Jr., and S. E. Sanderson. 2002. The dynamics of political discourse in seeking sustainability. Pages 147-169 in L. H. Gunderson and C. S. Holling, editors. Panarchy: understanding transformations in human and natural systems. Island Press, Washington, D.C., USA.

Rexová, K., Y. Bastin, and D. Frynta. 2006. Cladistic analysis of Bantu languages: a new tree based on combined lexical and grammatical data. Naturwissenschaften 93(4):189-194.

Roberts, J. T., P. E. Grimes, and J. L. Manale. 2003. Social roots of blobal environmental change: a world-systems analysis of carbon dioxide emissions. Journal of World-Systems Research 9 (2):277-315. Available online at: http://jwsr.ucr.edu// archive/vol9/number2/pdf/jwsr-v9n2-rgm.pdf.

Schumpeter, J.A. 1939. Business cycles. McGrawHill, New York, New York, USA.

Schumpeter, J.A. 1943. Capitalism, socialism, and democracy. Second edition. Allen and Unwin, London, UK.

Smith, A. 2003. Transforming technological regimes for sustainable development: a role for alternative technology niches. Science and Public Policy 30(2): 127-135.

Van der Brugge, R., J. Rotmans, and D. Loorbach. 2005. The transition in Dutch water management. Regional Environmental Change 5 (4):164-176.

Vogel, J. O. 1997. Eastern and south-central African iron age. Pages 439-443 in J. O. Vogel, editor. Encyclopedia of precolonial Africa: archaeology, history, languages, cultures and environments. AltaMira Press, Walnut Creek, California, USA.

Walker, B. H., L. H. Gunderson, A. P. Kinzig, C. Folke, S. R. Carpenter, and L. Schultz. 2006. A handful of heuristics and some propositions for understanding resilience in social-ecological systems. Ecology and Society 11(1):13. [online] URL: http://www.ecologyandsociety.org/vol11/iss1/ art13/.

Walker, B. H., and J. A. Meyers. 2004. Thresholds in ecological and social-ecological systems: a developing database. Ecology and Society 9(2):3. [online] URL: http://www.ecologyandsociety.org/vol9/ iss $2 / \operatorname{art} 3 /$.

Wallerstein, I. M. 1974. The modern world-system. Volume 1. Capitalist agriculture and the origins of the European world-economy in the sixteenth 
century. Cambridge University Press, Cambridge, UK.

Wallerstein, I. M. 1993. World system vs. worldsystems, a critique. Pages 292-296 in A. G. Frank and B. K. Gills, editors. The world-system: five hundred years or five thousand. Routledge, London, UK. 